\title{
Adsorption of synthetic dyed wastewater using activated carbon from rice husk
}

\author{
Anokhaa Kheddo ${ }^{1} \cdot$ Lydia Rhyman $^{2,3} \cdot$ Mohamed I. Elzagheid $^{4} \cdot$ Pratima Jeetah $^{1} \cdot$ Ponnadurai Ramasami $^{2,3}$
}

Received: 13 April 2020 / Accepted: 19 November 2020 / Published online: 8 December 2020

(c) Springer Nature Switzerland AG 2020

\begin{abstract}
The purpose of this study was to remove dyes from synthetic dyed wastewater using activated carbon derived from rice husk. The initial dye concentration was $45 \mathrm{mg} / \mathrm{L}$. The batch adsorption worked best in an acidic medium of $\mathrm{pH} 2$, adsorbent dosage of $13 \mathrm{~g} / \mathrm{L}$ and agitation speed of $100 \mathrm{rpm}$ with maximum dye removal of $80 \%$ after $10 \mathrm{~min}$. The maximum adsorption capacity of the absorbent was found to be $2.0 \mathrm{mg} / \mathrm{g}$ with a final dye concentration of $10.8 \mathrm{mg} / \mathrm{L}$. The adsorption was found to be a non-spontaneous, endothermic chemisorption process with less disorder which best fitted the Temkin model and followed pseudo-second order. For column adsorption, the highest $\mathrm{q}_{\mathrm{o}}$ corresponds to $12.8 \mathrm{mg} / \mathrm{g}$ and the maximum dye removal was above $99.5 \%$. Some of the experimental deductions were confirmed by gas-phase computations [B3LYP/6-31G(d)].
\end{abstract}

Keywords Adsorption · Activated carbon · Rice husk · Batch · Isotherms · Kinetic models · Column · DFT

\section{Introduction}

The progress in technology has led to the world achieving new prospects together with pollution problems and environmental disorders. Water pollution is mainly caused by the disposal of domestic, municipal and industrial wastes including textile industry which is considered to be one among the greatest polluters. Textile wastewaters are highly coloured due to unfixed dyes and these dyes must be separated from the wastewater because less than $1 \mathrm{mg} / \mathrm{L}$ can be visually detected [1]. These are responsible for aesthetic concerns, hinder light penetration and damage to aquatic microorganisms and they are difficult to eliminate due to their complex structure. Dyes can also pass through the entire food chain causing biomagnifications [2]. In order to protect the aquatic ecosystem, there are certain stringent discharge standards applicable for industrial effluents.

Adsorption process is considered to be an efficient method to eliminate colours, organic pollutants, odours and oils [3]. Adsorption of dye combines two mechanisms namely adsorption and ion exchange which is controlled by several parameters, such as $\mathrm{pH}$, temperature, dye/ adsorbent interaction and contact time among others [4]. The precise nature of the bonding depends on the species involved and is commonly classified as chemisorption or physisorption [5].

Electronic supplementary material The online version of this article (https://doi.org/10.1007/s42452-020-03922-5) contains supplementary material, which is available to authorized users.

$\triangle$ Pratima Jeetah, p.jeetah@uom.ac.mu; $\bowtie$ Ponnadurai Ramasami, p.ramasami@uom.ac.mu|'Department of Chemical and Environmental Engineering, University of Mauritius, Réduit 80837, Mauritius. ${ }^{2}$ Computational Chemistry Group, Department of Chemistry, Faculty of Science, University of Mauritius, Réduit 80837, Mauritius. ${ }^{3}$ Department of Chemical Sciences, University of Johannesburg, Doornfontein, Johannesburg 2028, South Africa. ${ }^{4}$ Department of Chemical and Process Engineering, Jubail Industrial College, Jubail Industrial City 31961, Saudi Arabia. 
The wastewater treatment method is generally categorized into three main parts; physical, chemical and biological processes $[4,6,7]$ which involves four stages namely preliminary, primary, secondary and tertiary treatments [7]. Each of the above mentioned techniques consists of other sub-techniques that differs according to process conditions, chemicals used or removal mechanism. Some of the dye removal techniques are described in Table 1.

Activated carbon is commonly used as an adsorbent which gives a high quality treated effluent and is easy to use. Other advantages of using activated carbon are that they offer a good removal of a broad range of dyes [3], they can be cheap if low-cost adsorbent is used [2] and it is an environmentally friendly product. Some of the disadvantages include expensive regeneration [16], it cannot be used for disperse and vat dyes, some of the absorbents may be lost [5] and high generation of sludge which can cause difficulty in handling disposal. Ullhyan used activated carbon derived from low-cost adsorbents such as mustard stalk to remove dyes [16]. There are several studies where low cost adsorbents have been used for dye removal such as batch adsorption to remove Reactive

Table 1 Advantages and disadvantages of dye removal techniques

\begin{tabular}{|c|c|c|}
\hline Process & Advantages & Disadvantages \\
\hline Adsorption on activated carbon & $\begin{array}{l}\text { - Treated effluent is of a high-quality } \\
\text { - Good removal of a broad range of dyes } \\
\text { - Good adsorbent } \\
\text { - Easy } \\
\text { - Cheap if low-cost adsorbent is used }\end{array}$ & $\begin{array}{l}\text { - Regeneration could be expensive, cannot be } \\
\text { used for disperse and vat dyes, non-destruction } \\
\text { process, some absorbent may be lost } \\
\text { - Expensive commercial activation carbon } \\
\text { - Disposal problem }\end{array}$ \\
\hline Coagulation-flocculation & $\begin{array}{l}\text { - Economically feasible and simple } \\
\text { - Complete removal of dye }\end{array}$ & $\begin{array}{l}\text { - High generation of sludge } \\
\text { - Difficulty in handling and for disposal }\end{array}$ \\
\hline Electrochemical processes & $\begin{array}{l}\text { - Non-hazardous breakdown compound } \\
\text { - No chemicals required and no generation of } \\
\text { sludge }\end{array}$ & $\begin{array}{l}\text { - Sludge of iron hydroxide } \\
\text { - High cost of electricity } \\
\text { - A direct decrease in dye removal due to relatively } \\
\text { high flow rates }\end{array}$ \\
\hline Physisorption & $\begin{array}{l}\text { - Efficiently remove high initial dye concentration } \\
\text { and regenerates }\end{array}$ & - Expensive \\
\hline Chemisorption & - Efficiently remove high dye concentration & - Expensive, difficult to regenerate \\
\hline Membrane filtration & $\begin{array}{l}\text { - Removal of all types of dyes } \\
\text { - A high-quality treated effluent is obtained } \\
\text { - Maximum removal of initial high dye concentra- } \\
\text { tions }\end{array}$ & $\begin{array}{l}\text { - Concentrated sludge generation } \\
\text { - Expensive, high pressures and cannot treat large } \\
\text { amount of wastewater } \\
\text { - Concentration polarisation and membrane fouling }\end{array}$ \\
\hline Fenton's reagent & $\begin{array}{l}\text { - Effective decolourisation of both insoluble and } \\
\text { soluble dyes } \\
\text { - Cost effective and environmentally friendly, high } \\
\text { removal for many brands of dyes, faster reaction } \\
\text { and degradation time, no need of complicated } \\
\text { instruments }\end{array}$ & $\begin{array}{l}\text { - Usage of } \mathrm{Fe}^{2+} \text { produced sludge } \\
\text { - Generate excess heat, expensive operational } \\
\text { cost for high contaminants concentration, high } \\
\text { production of iron sludge }\end{array}$ \\
\hline lon exchange & $\begin{array}{l}\text { - Possibility of regeneration: no adsorbent loss } \\
\text { - Effective }\end{array}$ & $\begin{array}{l}\text { - Ineffective for some types of dye, particularly, } \\
\text { disperse dyes } \\
\text { - Economical restrictions }\end{array}$ \\
\hline Photochemical & $\begin{array}{l}\text { - No sludge production } \\
\text { - Reduction of foul odours } \\
\text { - Mineralisation of organic compounds, cheap } \\
\text { semiconductors }\end{array}$ & $\begin{array}{l}\text { - Formation of by-products } \\
\text { - Lower efficiency at high initial dye concentration }\end{array}$ \\
\hline Oxidation & $\begin{array}{l}\text { - Process is rapid and efficient } \\
\text { - Simple application }\end{array}$ & $\begin{array}{l}\text { - High cost of energy } \\
\text { - Require chemicals }\end{array}$ \\
\hline Advanced oxidation process & $\begin{array}{l}\text { - No sludge generation } \\
\text { - Efficient for recalcitrant dyes, } \\
\text { - Little utilization of chemicals }\end{array}$ & $\begin{array}{l}\text { - Technical restrictions } \\
\text { - By-products formed } \\
\text { - Economically unfeasible }\end{array}$ \\
\hline Biodegradation & - Economically feasible & - Slow process \\
\hline Irradiation & - Effective oxidation at laboratory scale & - Need a lot of dissolved oxygen \\
\hline Ozonation & $\begin{array}{l}\text { - Applied in gaseous state } \\
\text { - No increase in amount of wastewater and sludge }\end{array}$ & - Short half-life about 20 min of ozone \\
\hline
\end{tabular}

Adapted from: Tripathi [8]; Bizuneh [4]; Kumar et al. [7]; Pereira and Alves [9]; Salleh et al. [10]; Wang et al. [11]; Parvathi et al. [12]; Demirbas [13]; Mishra [14]; Babu et al. [15]

\section{SN Applied Sciences}


Red 195 (RR195) dye using chitosan padded wheat husk and chitosan rice husk under optimised conditions, the efficiency was $79 \%$ and $83 \%$, respectively [17]. The use of Georgenia sp. CC-NMPT-T3 to degrade and remove RR195 under optimised condition of $\mathrm{pH} 7.0$ and temperature of $40{ }^{\circ} \mathrm{C}$, with an efficiency of $95.93 \%$ at $50 \mathrm{ppm}$ within $5 \mathrm{~h}$ [18]. Batch adsorption experiment was also carried out to remove Chemazol RR195 using dehydrated beet pulp carbon [19]. At $50^{\circ} \mathrm{C}$ and optimum pH of 1.0 , the maximum dye capacity was observed to be $58.0 \mathrm{mg} / \mathrm{g}$ and equilibrium was reached at $180 \mathrm{~min}$. The adsorption process was spontaneous and endothermic [19]. Cone biomass of Pinus sylvestris Linneo was also used to study the biosorption of RR195 from aqueous solution. The maximum $\mathrm{pH}$ was 1.0 and the capacity of the biosorption increased from $6.69 \mathrm{mg} / \mathrm{g}$ to $7.38 \mathrm{mg} / \mathrm{g}$ when the temperature was increased from $20^{\circ} \mathrm{C}$ to $50^{\circ} \mathrm{C}$ for $200 \mathrm{mg} / \mathrm{L}$ dye concentration. The experimental data followed pseudo-second order [20]. There are also reports on the use of activated carbon from rice husk to remove reactive dye [21], methylene blue dye [3] and Janus Green B dye [22].

In view of the above and in continuation with a previous research [23], activated carbon derived from rice husk was used as the adsorbent since it is considered to be an agricultural carbonaceous waste. The primary objective of this study was to investigate the use of the activated carbon from rice husk in removing synthetic dye from wastewater. Within, these objectives, our aims were to; (1) determine the optimum $\mathrm{pH}$, adsorbent dosage, agitation speed for batch adsorption, (2) analyse batch equilibrium isotherms, (3) study the thermodynamics and kinetics of the batch adsorption behaviour, (4) determine the optimum bed height for column adsorption and the results were analysed using Thomas model and (5) calculate the binding energy of RR195 onto pyrene using
B3LYP/6-31G(d) method. The novelty of this study is that actual dye wastewater was prepared and treated while most reports focused on the treatment of dye solution.

\section{Materials and methods}

This section describes the experimental and computational methods adopted in this research work and the characterisation of the original and treated samples like the $\mathrm{pH}$, level of nitrates, nitrites, phosphates, sulfates, total suspended solids (TSS), biochemical oxygen demand (BOD) and chemical oxygen demand (COD).

\subsection{Synthetic dyed wastewater}

Synthetic dyed wastewater was prepared by mimicking the hot exhaust dyeing process as illustrated in Fig. 1 at laboratory scale using pre-treated cotton fabric and Sumifix Supra Brilliant Red 3BF known as RR195 [24], an azo dye, as shown in Fig. 2, dyed at $2 \%$ shade on mass of fabric and a fabric/liquor ratio of 1:50. According to the fabric/ liquor ratio, $20 \mathrm{~g} / \mathrm{L}$ alkali (sodium carbonate, $\mathrm{Na}_{2} \mathrm{CO}_{3}$ ) and $30 \mathrm{~g} / \mathrm{L}$ salt (sodium sulfate, $\mathrm{Na}_{2} \mathrm{SO}_{4}$ ) were added. After the dyeing process, the dyed fabric was removed from the dye bath and was rinsed thoroughly using water and boiled for $15 \mathrm{~min}$ followed by cold water. The exhausted dye bath, soaping dye bath and the rinsing water were collected and mixed thoroughly to form the synthetic dyed wastewater.

The optimum wavelength of RR195 dye was determined as a pre-requirement to obtain the calibration curve. Initial dye concentration was measured at the beginning of each experiment using the calibration curve and it was found to be mostly at $45 \mathrm{mg} / \mathrm{L}$.

Fig. 1 Profile of dyeing process

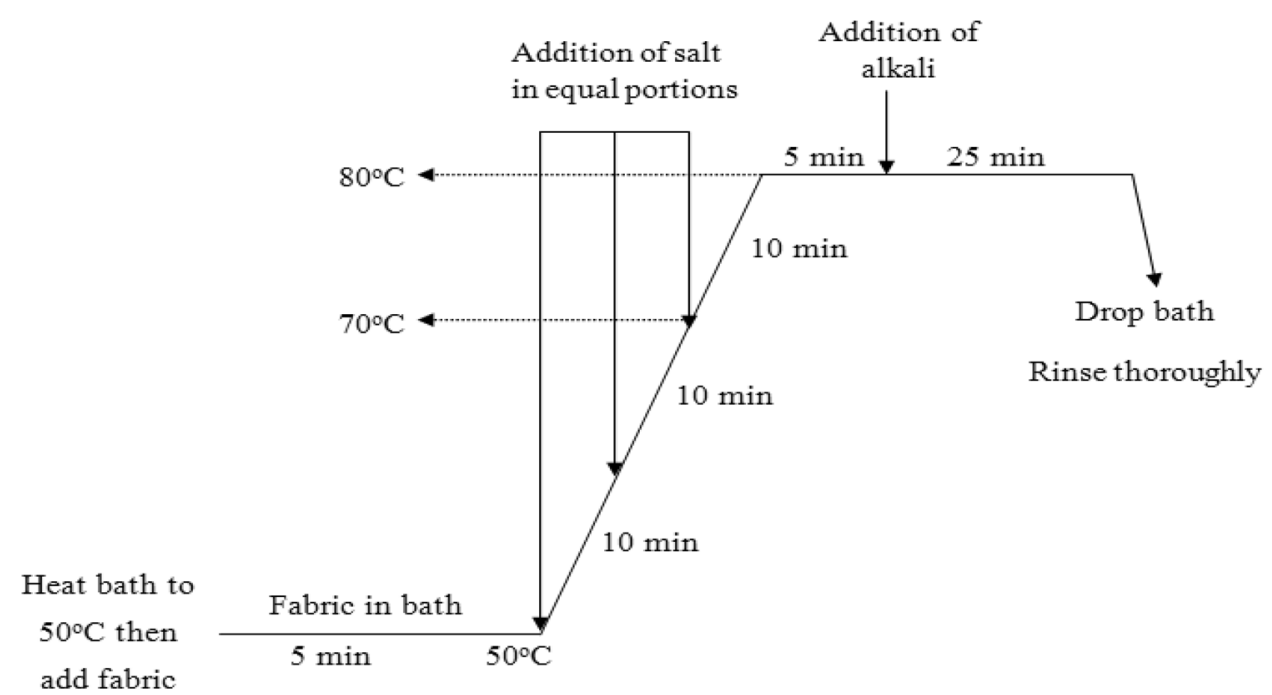


Fig. 2 Structure of RR195 dye [20]

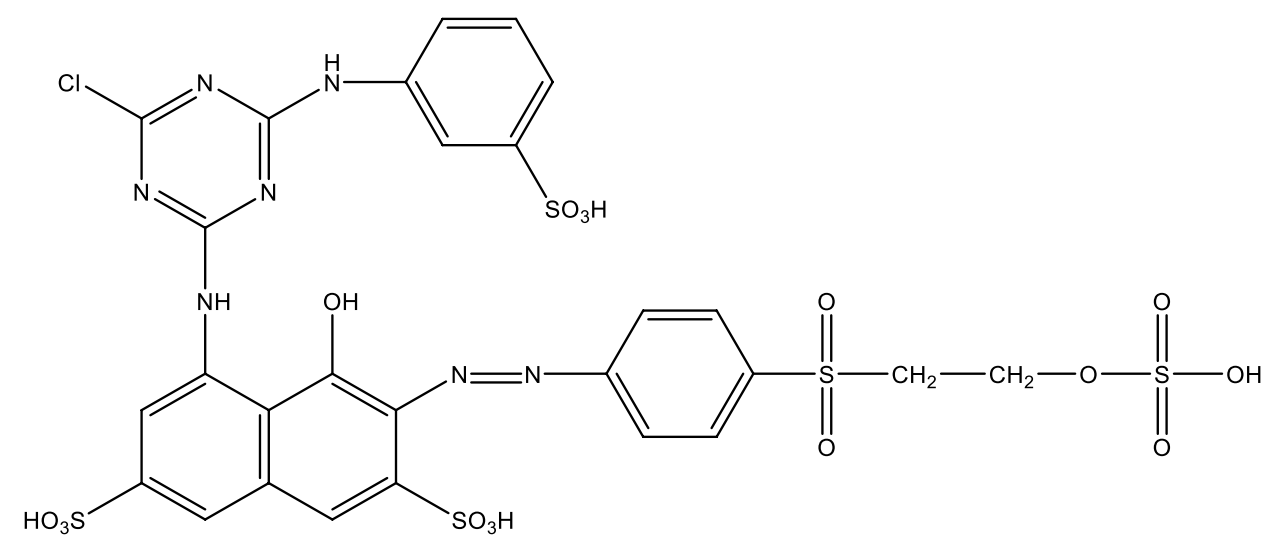

During the dyeing process, according to the fabric/ liquor ratio of $1: 50,20 \mathrm{~g} / \mathrm{L}$ alkali, (sodium carbonate, $\mathrm{Na}_{2} \mathrm{CO}_{3}$ ) and $30 \mathrm{~g} / \mathrm{L}$ salt (sodium sulfate, $\mathrm{Na}_{2} \mathrm{SO}_{4}$ ) were added. $\mathrm{Na}_{2} \mathrm{SO}_{4}$ and $\mathrm{Na}_{2} \mathrm{CO}_{3}$ were added in order to achieve exhaustion and fixation of dye, respectively. However, $\mathrm{Na}_{2} \mathrm{CO}_{3}$ is responsible for the increase of the dyebath's $\mathrm{pH}$ which resulted in an alkaline wastewater. Sulfate was higher due to the usage of $\mathrm{Na}_{2} \mathrm{SO}_{4}$. The effect of sodium carbonate and sodium sulfate on adsorption was not determined.

\subsection{Preparation of activated carbon from rice husk}

Dried rice husks were used to prepare different types of activated carbon which were tested by performing batch experiments to determine the suitable activation agent, activation time and temperature and particle size. Different activation agents have different effects on the activated carbon due to their intrinsic behaviours during chemical activation which eventually play a significant role in the carbon yield and adsorption performance. $3 \mathrm{~kg}$ of rice husk was collected and they were oven dried at $60^{\circ} \mathrm{C}$, for $24 \mathrm{~h}$ to remove moisture. After $24 \mathrm{~h}$, the dried rice husks were then reduced to particle size ranging from 28 mesh to 115 mesh. This was performed to increase the surface area offered by the adsorbent for adsorption. They were retained in a sealed air-tight container for subsequent use. They were then subjected to the activation process whereby about $2240 \mathrm{~g}$ of activated carbon was obtained from $3 \mathrm{~kg}$ of rice rusk amounting to about $74 \%$ yield. Each test was done in triplicates. For this study, concentrated sulfuric acid, phosphoric acid of $85-88 \%$ and orthophosphoric acid of $85 \%$ were used. For the trials, the conditions set were original $\mathrm{pH}$ of wastewater, adsorbent dosage of $5.0 \mathrm{~g} / \mathrm{L}$, agitation speed of $150 \mathrm{rpm}$ and agitation time of $100 \mathrm{~min}$. The trials were performed on granular ACRH of 28 mesh and powdered ACRH of 115 mesh. For sulfuric acid with impregnation ratio of $1: 1(w / v) \%$, the highest percentage dye removal was found to be $32.1 \%$ and $36.8 \%$ for
Granular AC (GAC) and Powdered AC (PAC), respectively, at $350{ }^{\circ} \mathrm{C}$ for $30 \mathrm{~min}$. The yield was found to be $70.4 \%$. While for phosphoric acid using impregnation ratio of $1: 2(w / v) \%$, the highest efficiency was found to be at $30 \mathrm{~min}$ for both GAC and PAC which gave the highest \% dye removal of $36.6 \%$ with GAC and $44.0 \%$ with PAC. The highest yield was $51 \%$ at an activation time of $45 \mathrm{~min}$. For the orthophosphoric acid using impregnation ratio of $2: 1(\mathrm{w} / \mathrm{v}) \%$, it was observed that AC prepared at activation temperature of $350{ }^{\circ} \mathrm{C}$ showed the highest $\%$ dye removal of $45.0 \%$ with GAC and $49.0 \%$ for PAC. Moreover, the yield was $74.8 \%$ which is the highest compared to the others. Thus AC prepared from orthophosphoric acid with impregnation ratio of 2:1 (w/v)\%, activation temperature of $350^{\circ} \mathrm{C}$ and activation time of $30 \mathrm{~min}$ were the most suitable ACRH. It was also the most cost-effective ACRH due to its impregnation ratio, high yield of $74.75 \%$ and low activation time.

\subsection{Optimum pH}

Optimum $\mathrm{pH}$ was determined by batch experiments using adsorbent dosage of $5.0 \mathrm{~g} / \mathrm{L}$ and agitation speed of $150 \mathrm{rpm}$ at room temperature. $1 \mathrm{M} \mathrm{HCl}$ and $1 \mathrm{M} \mathrm{NaOH}$ were prepared in bulk and were added to adjust the $\mathrm{pH}$ dropwise followed by the addition of the adsorbent and this was allowed to run on an orbital shaker for $120 \mathrm{~min}$. The samples were filtered through $90 \mathrm{~mm}$ Whatman filter paper and the absorbance was recorded at $540 \mathrm{~nm}$.

\subsection{Batch adsorption}

Batch adsorption experiments were carried out at optimum $\mathrm{pH}$ of 2 in $250 \mathrm{~mL}$ conical flask. For each batch process, $200 \mathrm{~mL}$ of dyed wastewater was poured into a $500 \mathrm{~mL}$ conical flask. The $\mathrm{pH}$ of the wastewater was adjusted using $1 \mathrm{M} \mathrm{HCl}$ and $1 \mathrm{M} \mathrm{NaOH}$. The conical flask was placed on an orbital shaker. The adsorbent was added to it and the shaker was allowed to run for $120 \mathrm{~min}$. As from this point, samples were taken for 10 and 30 min agitation time since 
the optimum time of all the trials were found to be $20 \mathrm{~min}$. The samples were filtered through the $90 \mathrm{~mm}$ Whatman filter paper. $10 \mathrm{~mL}$ of the filtrate was poured in different spectrophotometer vials. The absorbance of each sample was recorded at $540 \mathrm{~nm}$ to determine the optimum adsorbent dosage using constant agitation rate of $150 \mathrm{rpm}$ and optimum agitation speed using the optimum adsorbent dosage as shown in Fig. 3.

The dye concentration on adsorbent was calculated using Eq. (1).

$q_{t}=\frac{\left(C_{o}-C_{t}\right) V}{m}$

where $C_{o}$ is the initial dye concentration $(\mathrm{mg} / \mathrm{L}), C_{t}$ is the residual dye concentration in solution/wastewater at time $t(\mathrm{mg} / \mathrm{L}), \mathrm{V}$ is volume $(\mathrm{L})$ and $\mathrm{m}$ is the mass of the adsorbent (g).

The experimental data were analysed using Langmuir, Freundlich, Dubinin-Radushkevich and Temkin isotherms. Thermodynamics studies at room temperature and kinetic studies were employed for batch experimental data obtained for different adsorbent dosages and agitation speeds.

\subsection{Column adsorption}

The column adsorption experiments were conducted in a glass column with a diameter of $5 \mathrm{~cm}$ and length of $50 \mathrm{~cm}$. The column was filled with a small layer of cotton and a small layer of granular ACRH at the bottom to prevent drainage of powdered ACRH. Then, the column was mounted up with equal layer of powdered ACRH followed by granular ACRH. The system was set up like a filtration process as shown in Fig. 4.
Fig. 4 Column adsorption set up

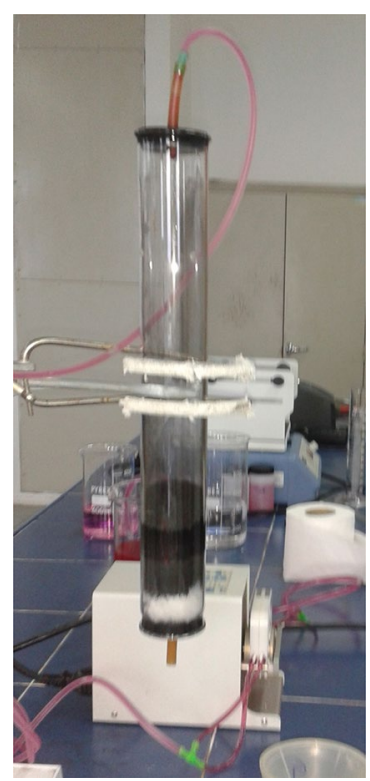

The column experiments were performed at optimum $\mathrm{pH} 2$, room temperature, contact time of $10 \mathrm{~min}$ and at height of 3,5 and $7 \mathrm{~cm}$. In order to maintain the contact time of $10 \mathrm{~min}$, the volumetric flow rate for each bed height was calculated by dividing the volume by time. The sample was collected at every 10 min interval for $160 \mathrm{~min}$ and the Thomas model was employed to analyse the results. Thomas model was used to investigate the column performance and breakthrough behaviour of RR195 onto ACRH for the column experiments.

\subsection{Characteristics of original and treated samples}

The treated samples were collected from both experiments at highest dye removal. $\mathrm{pH}$, level of nitrates, nitrites,
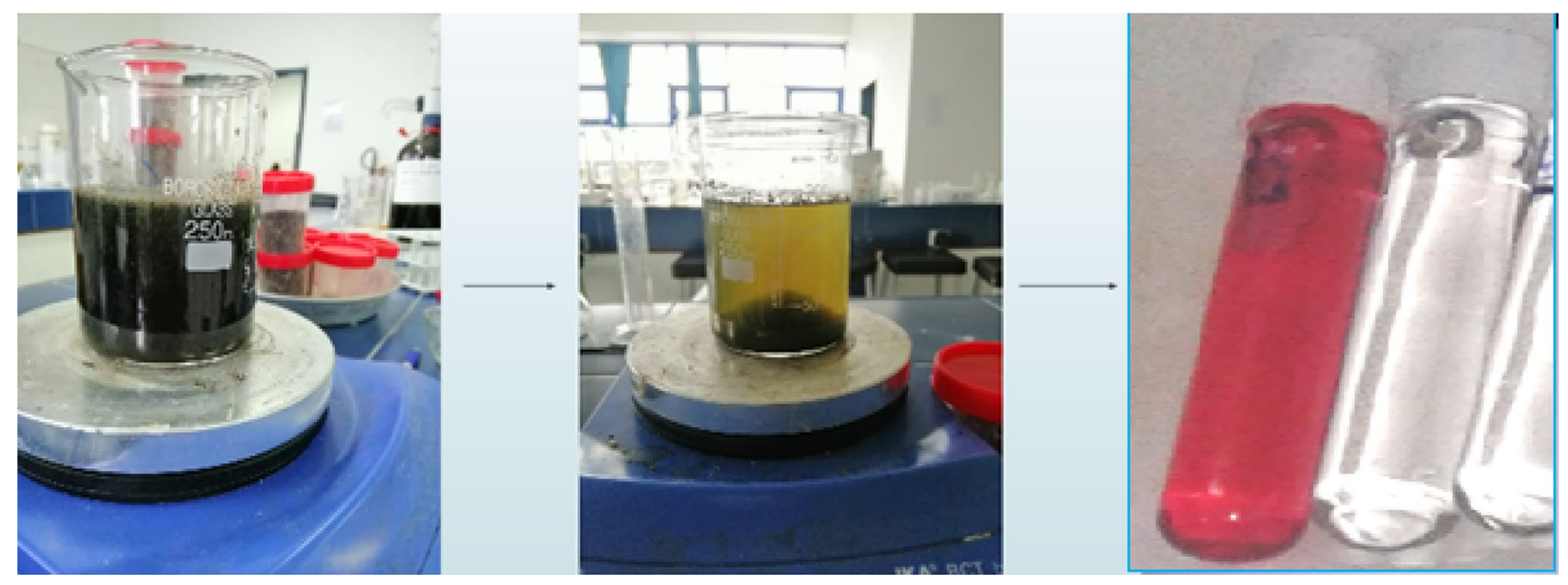

Fig. 3 Batch adsorption 
phosphates, sulfates, total suspended solids (TSS), biochemical oxygen demand (BOD) and chemical oxygen demand (COD) were determined using standard methods.

\subsection{Computational method}

Activated carbon from rice husk was modeled as pyrene based on the report by Saleh et al. [25]. Theoretical calculations based on the density functional theory (DFT) method were carried out to determine the binding energy of the dye RR195 onto pyrene. Computations were carried out using Gaussian 09 [26] program package running on SEAGrid [27-30]. The B3LYP functional in conjunction with the 6-31G(d) basis set for all atoms were employed based on the previous study [25]. Full geometry optimisations on RR195 and pyrene were carried out and verified by frequency computations. RR195 was positioned at five different locations on pyrene and the complex was optimised separately. The binding energy which is the energy needed to disassemble atoms into separate parts was calculated using Eq. (2).

Binding energy $=E_{1}+E_{2}-E_{3}$

where, $E_{1}, E_{2}$ and $E_{3}$ represent the electronic energy of the dye RR195, pyrene and the complex, respectively.

\section{Results and discussion}

The results of the experimental analysis and calculations are presented in this section.

\subsection{Characteristics of activated carbon from rice husk}

The $\mathrm{pH}$ of the $\mathrm{ACRH}$ was 7 as it was carefully adjusted while washing. The moisture contents of the powdered ACRH and granular ACRH were $4.696 \%$ and $4.963 \%$, respectively and the bulk density of powdered ACRH was $459.2 \mathrm{~kg} / \mathrm{m}^{3}$ while granular ACRH was $181.5 \mathrm{~kg} / \mathrm{m}^{3}$. The activated carbon obtained was black in colour as shown in Fig. 5 .

\subsection{Optimum pH}

Figure 6 illustrates the percentage dye removal at different $\mathrm{pH}$ with an agitation time of $10 \mathrm{~min}$ which is the maximum dye removal after the experiment was conducted for $2 \mathrm{~h}$. It was observed that $64.3 \%$ of $\mathrm{RR} 195$ was removed at $\mathrm{pH} 2.0$

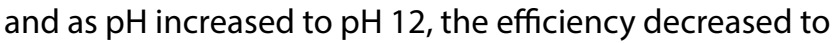
$48.1 \%$. Previous studies reported that an acidic medium is required for some direct, reactive and acidic dyes such as acid blue 113 and direct blue 80 [31] for different

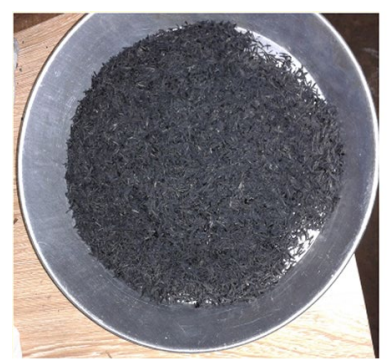

(a)

Fig. 5 (a) Granulated activated carbon (GAC) (b) Powdered activated carbon (PAC)

adsorbents while an alkaline medium is essential for basic dye like methylene blue [32].

The initial $\mathrm{pH}$ has a significant role on adsorption capacity as it controls the surface charge of the adsorbent and the degree of ionisation of materials found in the adsorbate [33]. In this study, the ACRH had an initial pH of 7 and increasing the $\mathrm{pH}$ promotes alkaline medium of the $\mathrm{ACRH}$ which resulted in a net negative charge. Therefore, an increase in $\mathrm{pH}$ led to the deprotonation of the surface groups resulting in electrostatic repulsion [32, 33]. At pH 2, there was protonation which eventually led to a net positive charge surface on the activated carbon resulting in electrostatic attraction between ACRH and RR195.

\subsection{Optimum adsorbent dosage}

From Fig. 7, it can be observed that the percentage dye removal increased from $49.5 \%$ to $76.6 \%$ with increasing adsorbent dosages, at $13.0 \mathrm{~g} / \mathrm{L}$ there was a steady point however beyond this point, the curve gave a decreasing trend. The increase in efficiency might be due to greater surface area and greater number of active sites [21]. Aggregation of particles reduced the availability of binding sites for adsorption of dyes which might be the reason for the drop in efficiency [34].

Further, a graph of percentage dye removal versus adsorbent dosage was plotted (Fig. 7) at $\mathrm{pH}=2$. The $\mathrm{R}^{2}$ values were greater than 0.95 which indicate good correlation and it can be deduced that $13.0 \mathrm{~g} / \mathrm{L}$ was the optimum adsorbent dosage.

\subsection{Optimum agitation speed}

Agitation speed should be enough to ensure that all the binding sites on the surface are easily accessible for dye adsorption [35]. From Fig. 8, it can be observed that the efficiencies increase with increasing agitation speeds from 50 to $100 \mathrm{rpm}$ but decrease from $150 \mathrm{rpm}$ to $300 \mathrm{rpm}$. This decrease in dye removal can be due to 
Fig. 6 Percentage dye removal at different $\mathrm{pH}$

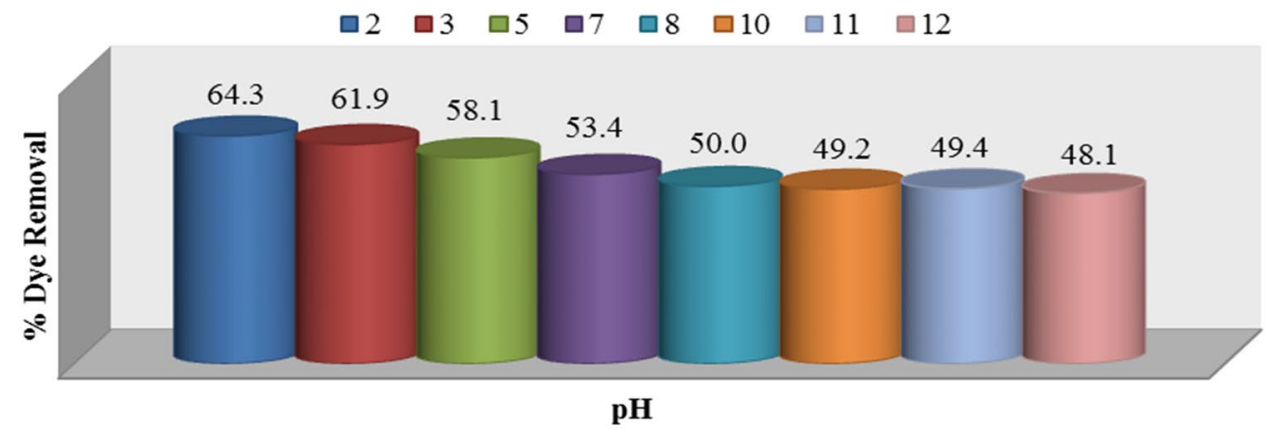

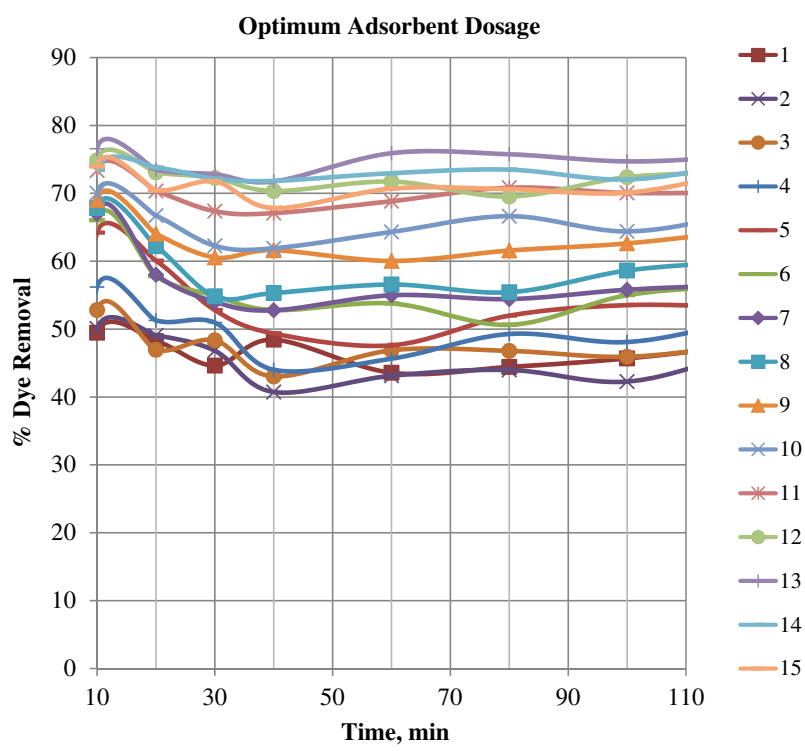

Fig. 7 Percentage dye removal for different adsorbent dosages at $\mathrm{pH}=2$

an increase in the desorption tendency of dye molecules. However, at $10 \mathrm{~min}$, there is a maximum dye removal above $70 \%$. This is because at $50 \mathrm{rpm}$ the $\mathrm{ACRH}$ was not spread and was gathered which obscured the active sites of the lower adsorbent's layer and therefore, allowing only the active sites on the upper layer to adsorb the dye [35].

Increasing the agitation rate from 50 to $100 \mathrm{rpm}$ can diminish the film boundary layer around the adsorbent particles and boosted the mass transfer coefficient of the external film [36] and hence, more dye was adsorbed. Another possibility is that the surface area of adsorbent is available to the whole volume of dye solution while shaking [37].

The efficiencies from 150 to $300 \mathrm{rpm}$ are constant and the effect of agitation has plateaued at $150 \mathrm{rpm}$ for the 10 min samples. The minimum effect pointed out that the external mass is not the only rate-limiting factor [32]. This decrease in dye removal can be due to an increase in the desorption tendency of dye molecules [35]. Hence, it can be deduced that further increase in the agitation speed would not have significant effect. Therefore, the optimum agitation speed was found to be $100 \mathrm{rpm}$.

\subsection{Equilibrium adsorption isotherms}

\subsubsection{Langmuir isotherm}

Langmuir models are valid for monolayer adsorption onto a surface containing a set of distinct localised adsorption active sites with similar adsorption energy, free of the surface coverage and having no interaction between
Fig. 8 Percentage dye removal at different agitation speeds

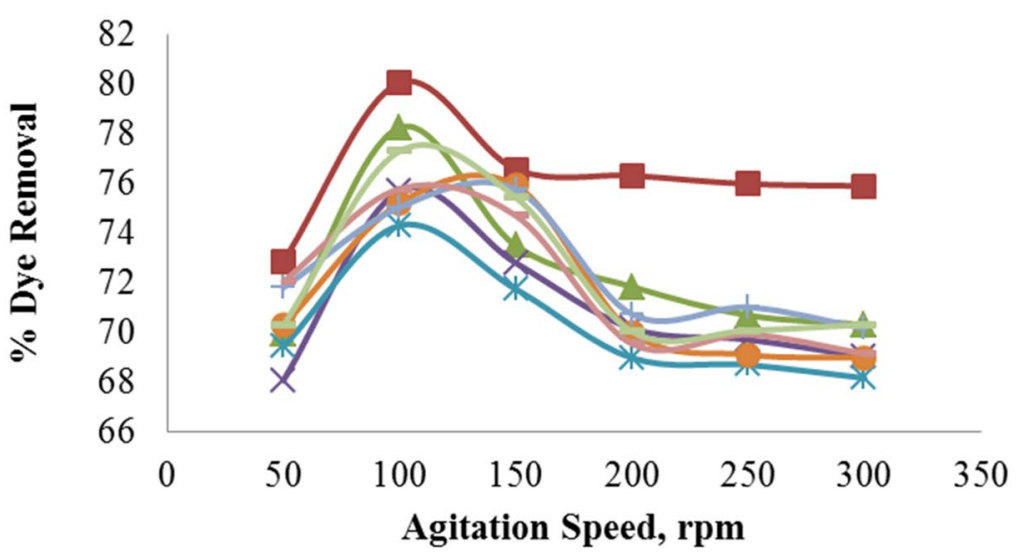


adsorbed molecules [38]. The monolayer adsorption capacity of the adsorbent and the $R_{L}$ values were found using Eqs. (3) and (4), respectively.

$\frac{C_{t}}{q_{t}}=\frac{1}{\left(K_{L} q_{\max }\right)}+\frac{C_{t}}{q_{\max }}$

$R_{L}=\frac{1}{\left(1+K_{L} C_{o}\right)}$

where $C_{t}$ is the residual dye concentration in solution/ wastewater at time $\mathrm{t}(\mathrm{mg} / \mathrm{L}), q_{t}$ is the dye concentration on adsorbent at time $t(\mathrm{mg} / \mathrm{g}), K_{L}$ is the Langmuir constant related to the rate of adsorption ( $\mathrm{L} / \mathrm{mg}), q_{\max }$ is the monolayer adsorption capacity of the adsorbent $(\mathrm{mg} / \mathrm{g})$ and $C_{o}$ is the initial dye concentration $(\mathrm{mg} / \mathrm{L})$.

When $0<R_{L}<1$, it implies favourable adsorption, $R_{L}=0$ indicates irreversible adsorption, $R_{L}=1$ refers to linear adsorption and $R_{L}>1$ means unfavourable adsorption $[22,39]$.

Langmuir isotherms are depicted in Figures SI1(a) and SI1 (b) for adsorbent dosages and agitation speeds, respectively and the results are summarised in Table SI1. The maximum adsorption capacity of some adsorbents are shown in Table 2. In this study, the maximum adsorption capacity of the absorbent was found to be $2.037 \mathrm{mg} / \mathrm{g}$ at optimum conditions and this shows that the surface of the activated carbon reached its saturation point. Further, both Langmuir isotherms indicate high $\mathrm{R}^{2}$ values however based on $R_{L}$ values, the isotherms are not appropriate since the $R_{L}$ values are negative due to negative $K_{L}$ values. Therefore, some modifications are necessary to allocate more freedom in the adsorption and desorption phases [44].

\subsubsection{Freundlich isotherm}

Freundlich isotherm is an empirical equation which presumes physicochemical adsorption on heterogeneous surfaces [43] implying that binding sites are not comparable and/or independent [19]. The formula used to find the Freundlich constants is given in Eq. (5) [45].

$\ln q_{t}=\ln K_{F}+\frac{1}{n} \ln C_{t}$

where $q_{t}$ is the dye concentration on adsorbent at time $t$ $(\mathrm{mg} / \mathrm{g}), K_{F}$ is the Freundlich constant related to the adsorption capacity of the absorbent, $n$ is the Freundlich constant which gives an indication of how favourable is the adsorption process and $C_{t}$ is the residual dye concentration in solution/wastewater at time $\mathrm{t}(\mathrm{mg} / \mathrm{L})$.

A value of $1 / n$ closer to 0 implies more heterogeneous adsorption [22], $1 / n<1$ means adsorption capacity is only slightly suppressed at lower equilibrium concentrations [45], $1 / n<1, n<10$ [46] and $n>1$ implies favourable adsorption [47].

Figures $\mathrm{SI2}(\mathrm{a})$ and $\mathrm{SI}$ (b) illustrate the Freundlich isotherm for different adsorbent dosages and different agitation speeds, respectively. The isotherms have high $\mathrm{R}^{2}$ values. The values of $n$ calculated in Table SI 2 were found

Table 2 Maximum adsorption capacity of some adsorbents

\begin{tabular}{|c|c|c|c|}
\hline Absorbent & Dye & $\mathrm{q}_{\max }, \mathrm{mg} / \mathrm{g}$ & References \\
\hline Activated carbon prepared from rice husk & Methylene blue & 333.33 & [3] \\
\hline Activated rice husk & Acid yellow 17 & 12.98 & {$[40]$} \\
\hline $\mathrm{NiFe}_{2} \mathrm{O}_{4}$ nanoparticles & $\begin{array}{l}\text { Anionic dyes of sunset yellow, tartrazine, } \\
\text { and Eriochrome black T }\end{array}$ & $72.21,75.88,82.04$ & {$[2]$} \\
\hline $\begin{array}{l}\text { Activated carbon produced from fruit juice industry } \\
\text { solid waste }\end{array}$ & Yellow 18 & 75.76 & {$[41]$} \\
\hline Sawdust & Methylene blue & 30.11 & {$[42]$} \\
\hline Commercial activated carbon & & 39.09 & \\
\hline Acid activated mustard stalk & Reactive blue 4 & 25.80 & {$[16]$} \\
\hline Physico-chemically treated rice husk & Reactive black 5 & 8.34 & {$[21]$} \\
\hline Iraqi date palm seeds activated carbon & Disperse blue & 8.13 & {$[43]$} \\
\hline Oxidized multi-walled carbon nanotubes & Janus Green dye & 56.00 & {$[33]$} \\
\hline Rice husk & Sulfur dye & 55.56 & {$[37]$} \\
\hline Activated rice husk & Janus Green B & 5.88 & {$[22]$} \\
\hline Dehydrated beet pulp carbon & Chemazol reactive red 195 & 58.00 & [19] \\
\hline \multirow[t]{2}{*}{ Rice husk } & Direct red-31 & 129.87 & [34] \\
\hline & Direct orange-26 & 66.67 & \\
\hline Activated carbon from durian peel & Basic green 4 & $303.00,312.50$ & {$[31]$} \\
\hline
\end{tabular}


to be negative, signifying unfavourable adsorption as reported by Igwe and Abia [48]. High $\mathrm{K}_{\mathrm{F}}$ value implies greater adsorption intensity [48] but increasing adsorbent dosage gave a low $\mathrm{K}_{\mathrm{F}}$ value and variation in agitation gave nearly constant $\mathrm{K}_{\mathrm{F}}$ values. Further, Huang, et al. [49] reported that if neither Langmuir nor Freundlich isotherm fit the data, it implies that there are ion exchange mechanisms.

\subsubsection{Dubinin-Radushkevich (D-R) isotherm}

$\mathrm{D}-\mathrm{R}$ isotherm is used to find the characteristic porosity as well as the apparent free energy of adsorption [50] and this is mathematically represented by Eqs. (6) and (7). D-R Model can be applied to distinguish the nature of adsorption by estimating the magnitude of the mean free energy of sorption, $E_{s}$ [41]. The mean free energy of sorption is calculated by Eq. (8) [50].

$\ln q_{t}=\ln q_{s}-K \varepsilon^{2}$

$\varepsilon=R T \ln \left(1+\frac{1}{C_{t}}\right)$

$E_{s}=(-2 K)^{-\frac{1}{2}}$

where $q_{t}$ is the dye concentration on adsorbent at time $t$ $(\mathrm{mg} / \mathrm{g}), q_{s}$ is the theoretical saturation capacity $(\mathrm{mol} / \mathrm{g}), \mathrm{K}$ is the constant related to adsorption energy of porosity factor $\left.\left(\mathrm{mol}^{2} / \mathrm{kJ}\right)^{2}\right), \varepsilon$ is the Polanyi adsorption potential $(\mathrm{kJ} /$ $\mathrm{mol}), \mathrm{R}$ is the universal gas constant $(\mathrm{J} / \mathrm{mol} / \mathrm{K}), \mathrm{T}$ is the temperature $C_{t}$ is the residual dye concentration in solution/ wastewater at time $t(\mathrm{mg} / \mathrm{L})$ and $E_{s}$ is the mean free energy of sorption $(\mathrm{kJ} / \mathrm{mol})$.

When $\mathrm{E}_{\mathrm{s}}<8 \mathrm{~kJ} / \mathrm{mol}$, it implies physical adsorption and $8<\mathrm{E}_{\mathrm{s}}<16 \mathrm{~kJ} / \mathrm{mol}$ implies chemical ion exchange adsorption [50]. In ion exchange, cations and anions from the fluid (wastewater) replace dissimilar ions of the same charge initially in the solid. The ion exchanger contains permanently bound functional groups of opposite charge-type.

$D-R$ isotherms are depicted in Figures $\mathrm{SI}(\mathrm{a})$ and $\mathrm{SI} 3(\mathrm{~b})$ and the calculated mean free energy is shown in Table SI3. It can be deduced that adsorbent dosages below $10 \mathrm{~g} / \mathrm{L}$ followed physical adsorption while adsorbent dosages of $11 \mathrm{~g} / \mathrm{L}$ to $15 \mathrm{~g} / \mathrm{L}$ as well as adsorption at different agitation speeds followed chemical ion exchange adsorption.

\subsubsection{Temkin isotherm}

Temkin isotherm determines the adsorption potential of adsorbent for adsorbates and forecasts a consistent distribution of binding energies over the surface binding adsorption sites depending on the density and allocation of functional groups both on the adsorbent and dye surfaces [50].

The linearised expression used for Temkin isotherm is given in Eq. (9).

$q_{t}=\left(\frac{R T}{b_{T}}\right) \ln C_{t}+\left(\frac{R T}{b_{T}}\right) \ln K_{T}$

where $q_{t}$ is the dye concentration on adsorbent at time $t$ $(\mathrm{mg} / \mathrm{g}), \mathrm{R}$ is the universal gas constant $(\mathrm{J} / \mathrm{mol} / \mathrm{K}), T$ is the temperature which was $298.15 \mathrm{~K}, b_{T}$ is the adsorption potential of the adsorbent and $K_{T}$ is the binding energy $(\mathrm{L} / \mathrm{g})$.

Temkin isotherms are graphically represented in Figures $\mathrm{SI}$ (a) and SI4(b) and a summary of the results is tabulated in Table SI4. The results show high $R^{2}$ values implying good linearity for all the adsorbent dosages. A slight decrease is observed in $\mathrm{K}_{\mathrm{T}}$ values with increasing adsorbent dosages but the $b_{T}$ values have an extensive range with highest value at $100 \mathrm{rpm}$.

\subsection{Thermodynamics studies}

Thermodynamics of adsorption provides an insight into the mechanism and its adsorption behaviour [41]. The temperature was assumed to be $298.15 \mathrm{~K}$ since all experiments were performed at room temperature. The equations for Gibbs free energy [50], enthalpy [51] and entropy [52] are given in Eqs. (10), (11) and (12), respectively.

$K_{T}=\exp \left(\frac{-\Delta G^{\circ}}{R T}\right)$

$\Delta Q=-\Delta H$

$\Delta G^{\circ}=\Delta H-T \Delta S$

where $K_{T}$ is the binding energy $(\mathrm{L} / \mathrm{g}), \Delta \mathrm{G}^{\circ}$ is the relative Gibbs free energy $(\mathrm{kJ} / \mathrm{mol}), \mathrm{R}$ is the universal gas constant $(\mathrm{J} / \mathrm{mol} / \mathrm{K}), T$ is the temperature which was $298.15 \mathrm{~K}, \Delta \mathrm{Q}$ is the variation of adsorption energy $(\mathrm{J} / \mathrm{mol})$ and $\Delta \mathrm{Q}=\mathrm{b}_{\mathrm{T}}$, $\Delta \mathrm{H}$ is the relative enthalpy $(\mathrm{J} / \mathrm{mol})$ and $\Delta \mathrm{S}$ is the relative entropy $(\mathrm{J} / \mathrm{mol} / \mathrm{K})$.

In chemisorptions, adsorption is achieved by endothermic or exothermic processes [39] and the positive enthalpy values imply that the adsorptions are endothermic. The Gibbs free energy is positive which implies that the adsorption is non-spontaneous and negative entropy suggests less disorder. It can also be observed that experiment performed at $\mathrm{pH} 2$, adsorbent dosage $13 \mathrm{~g} / \mathrm{L}$ and agitation speed $100 \mathrm{rpm}$ had the highest values for the thermodynamic studies. Ghaedi et al. [53] reported that 
the adsorption of methyl green onto chemically modified $\mathrm{RH}$ was an endothermic process.

\subsection{Kinetics studies}

Pseudo-first-order and pseudo-second-order were employed in this study whose linearised formulae are given in Eqs. (13) and (14), respectively [52].

$\log \left(q-q_{t}\right)=\log q_{e}-\left(\frac{K_{1}}{2.303}\right) t$

$\frac{t}{q_{t}}=\frac{1}{K_{2} q_{e}^{2}}+\frac{t}{q_{e}}$

where $q$ is the equilibrium adsorption capacity $(\mathrm{mg} / \mathrm{g}), q_{t}$ is the dye concentration on adsorbent at time $t(\mathrm{mg} / \mathrm{g}), q_{e}$ is the theoretical equilibrium adsorption capacity $(\mathrm{mg} / \mathrm{g})$, $K_{1}$ is the rate constant of pseudo-first-order adsorption $(1 / \mathrm{min}), t$ is the time $(\mathrm{min})$ and $K_{2}$ is the rate constant of pseudo-second-order adsorption (g/mg.min).

A graphical representation of varying adsorbent dosages and agitation speeds for pseudo-first-order model are shown in Figures SI5(a) and SI5(b), respectively, and that of pseudo-second-order are depicted in Figures SI6(a) and SI6(b). As observed in Table SI6, the values of $\mathrm{q}_{\mathrm{e}}$ for pseudo-second-order decreases with an increase in the adsorbent dosage. The $\mathrm{q}_{\mathrm{e}}$ values of pseudo-second-order for adsorbent dosages range from $10 \mathrm{~g} / \mathrm{L}$ to $15 \mathrm{~g} / \mathrm{L}$ for all the agitation speeds between $2 \mathrm{mg} / \mathrm{g}$ to $3 \mathrm{mg} / \mathrm{g}$ and those of pseudo-first-order were fluctuating. It can also be observed that all the $R^{2}$ values for pseudo-secondorder approach 1. Therefore, it can be deduced that the adsorption follows the pseudo-second-order kinetic model. Pseudo-second-order forecasts the behaviour over the entire series of studies [52] and assumes that chemisorption is the rate controlling step which involves valent forces through allocation or swapping of electrons between adsorbent and adsorbate [54] that is between ACRH and the dye RR195.

\subsection{Column experiments}

\subsubsection{Contact time}

The percentage dye removal of an adsorbent may increase or decrease with time and hence the variation may be either positive or negative [6]. In this study, contact time was considered to be $10 \mathrm{~min}$ by analysing the batch adsorption experiments and same was applied to column adsorption experiments. The initial fast colour removal was due to the existence of large quantity of vacant sites [21] which were positively charged and therefore, attracted the anionic dye RR195 resulting in maximum dye removal. With time, the number of active sites dwindled, resulting in reduction of adsorption efficiency [21]. Increase in contact time might cause aggregation of dye molecules making them nearly impossible to diffuse deeper into the structure of the absorbent at its maximum energy sites due to resistance to diffusion [16]. From the batch experiments, it can be noted that at 120 min, equilibrium was almost attained.

\subsubsection{Bed height}

The trend of percentage dye removal at different bed heights is depicted in Figure $\mathrm{SI}(\mathrm{a}$ (a). Bed heights of $3 \mathrm{~cm}$ and $7 \mathrm{~cm}$ have an efficiency of $99.14 \%$ and $99.96 \%$, respectively. Hence, it is obvious that the removal efficiencies do not change significantly with increase in the bed height at $10 \mathrm{~min}$.

From Figure SI7(b), it can be deduced that the breakthrough and exhaustion time increase with an increase in bed height which consequently extended the mass transfer zone [42]. Higher bed height possesses more fixation binding sites allowing adsorption of dyes [55]. It also offers a larger service area which increases the volume of wastewater to be treated $[42,52]$. Since the rate of adsorption is proportional to the adsorbent's surface area, there is an increase in the solute concentration of the effluent with a decrease in bed height. From Figures $\mathrm{SI}$ (a) and $\mathrm{SI}$ (b), it is concluded that bed height of $5 \mathrm{~cm}$ is the optimum bed height and is most economical in terms of cost and efficiency.

\subsubsection{Thomas model}

The linearised formula of Thomas model is given as Eq. (15) and the column data are depicted in Figure SI8.

$\left.\ln \left[\left(\frac{C_{o}}{C_{t}}\right)-1\right)\right]=\left(\frac{K_{T h} q_{o} W}{Q}\right)-\left(K_{T h} C_{o} t\right)$

where $C_{o}$ is the initial dye concentration $(\mathrm{mg} / \mathrm{L}), C_{t}$ is the residual dye concentration in solution/wastewater at time $\mathrm{t}(\mathrm{mg} / \mathrm{L}), K_{T h}$ is the Thomas rate constant (L/min.mg), $q_{0}$ is the maximum column adsorption capacity $(\mathrm{mg} / \mathrm{g}), W$ is the mass of adsorbent in column (g) and $t$ is the time (min).

From Table SI7, it can be deduced that as the bed depth increases, the value of $\mathrm{K}_{\mathrm{Th}}$ decreases significantly from $3 \mathrm{~cm}$ to $5 \mathrm{~cm}$, however, at $5 \mathrm{~cm}$ and $7 \mathrm{~cm}$, it decreases slightly. The value of $\mathrm{q}_{\mathrm{o}}$ is also increased considerably from $3 \mathrm{~cm}$ to $5 \mathrm{~cm}$. The highest $\mathrm{q}_{o}$ is that of $7 \mathrm{~cm}$ corresponding to $12.8 \mathrm{mg} / \mathrm{g}$. The $R^{2}$ values of $5 \mathrm{~cm}$ and $7 \mathrm{~cm}$ bed height can be explained by the fact that from the start of the experiment till $160 \mathrm{~min}$, the column was still 
performing efficiently with almost $100 \%$ dye removal and hence, there was a long way to go before breakthrough. Therefore, the Thomas model is best fit with $3 \mathrm{~cm}$ with a $R^{2}$ value of 0.9210 .

\subsection{Characteristics of original and treated samples}

The characteristics of the prepared synthetic dyed wastewater and the treated samples were tested for various parameters and the values are collected in Table SI8. It was found that the principal inorganic pollutants were nitrates, nitrites, phosphates and sulfates, resulting from impurities found in the chemicals used. However, sulfate imparts hardness of water and may be converted to sulfur or hydrogen sulfide depending upon the redox potential of water [37]. TSS was high due to the unfixed dyes, starchy enzymes, colloidal particles or precipitated chemicals. The presence of oxidisable compounds resulted in greater COD values than BOD values [56] as well as due to colloidal matter, since chemicals used or starch found in the cotton fabric could have leached in the dyebath. The ratio of BOD:COD was found to be in the range of 0.2 to 0.35 , hence it can be deduced that the wastewater contains a major part of non-biodegradable matter [37].

From Table SI8, it can be deduced that the adsorption of the dye RR195 using ACRH had effectively treated the original wastewater. However, for batch experiments, there are some parameters such as $\mathrm{pH}$ and sulfate which should be treated further in order to comply with the norms set.

\subsection{Computational chemistry}

The structures of the dye RR195 and pyrene are shown in Figs. 9a, b, respectively while all the optimised geometries are illustrated in Figs. 10a-e. The optimised structures at each position are denoted as complex P1, P2, P3, P4 and $P 5$. The calculated binding energies of each complex are summarised in Table 3.
The variation in binding energies indicates that the adsorption was more sensitive towards the nature of the functional group. Activation energy of $5-40 \mathrm{~kJ} / \mathrm{mol}$ is considered to be physisorption [57]. Complex P3 undergoes chemisorption process as it was reported that chemical adsorption has activation energy between 40 and $800 \mathrm{~kJ} /$ mol [57]. This deduction is in accordance with the swapping of electrons which can be observed in Fig. 7c [54]. Furthermore, the binding energy of complex $\mathrm{P} 3$ indicates that it undergoes an endothermic chemisorption process [58]. The theoretical findings for complex P3 is in agreement with the experimental analysis whereby at optimum conditions, the adsorption favoured endothermic chemical ion exchange process.

\section{Conclusion}

1. The optimum conditions for batch adsorption were found to be at $\mathrm{pH} 2$ with an adsorbent dosage of $13 \mathrm{~g} / \mathrm{L}$ and agitation speed of $100 \mathrm{rpm}$ with highest percentage dye removal of $80 \%$ at agitation time of $10 \mathrm{~min}$ and at $120 \mathrm{~min}$ and the percentage dye removal was nearly plateaued for most of the experiments. The optimal conditions were validated using the verification experiment whereby it was found that they have a relative standard deviation less than $5 \%$. This suggests that the experiments performed were precise and hence can be considered as optimal.

2. Based on the $R^{2}$ values ranging from 0.9987 to 0.9994 , it was observed that Temkin isotherm has the best fit.

3. At optimum conditions, Dubinin-Radushkevich isotherms indicate that the adsorption followed a chemisorption process with $E_{S}$ value of $13.36 \mathrm{~kJ} / \mathrm{mol}$.

4. The adsorption process was a non-spontaneous, endothermic process with less disorder which followed the pseudo-second-order kinetic model.

Fig. 9 (a) Reactive red 195 dye. (b) Pyrene

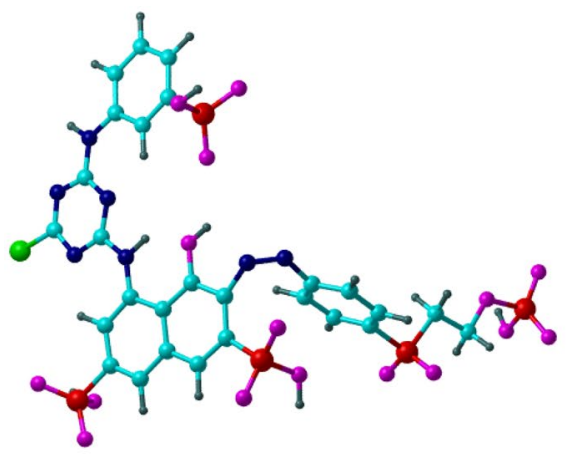

(a) Reactive red 195 dye

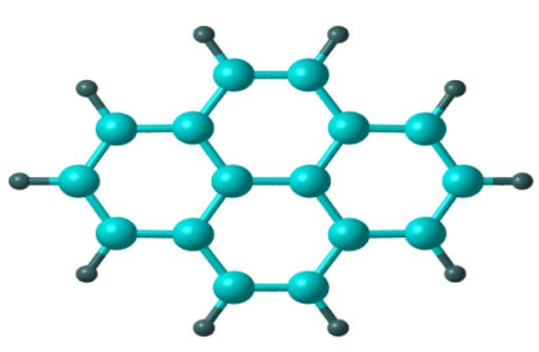

(b) Pyrene 


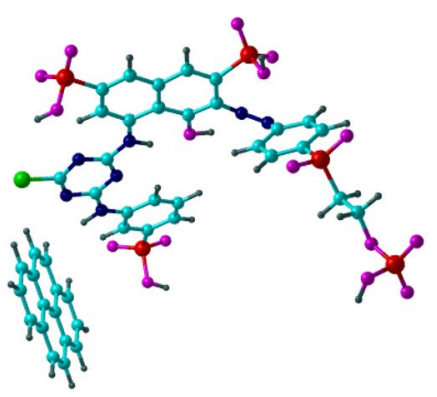

(a) Complex P1

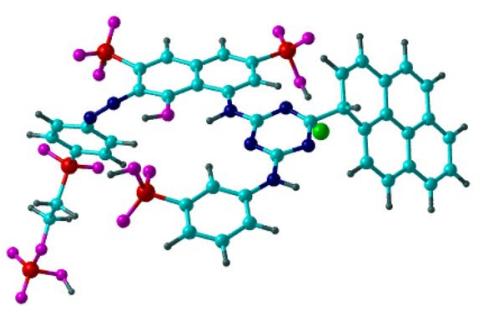

(d) Complex P4

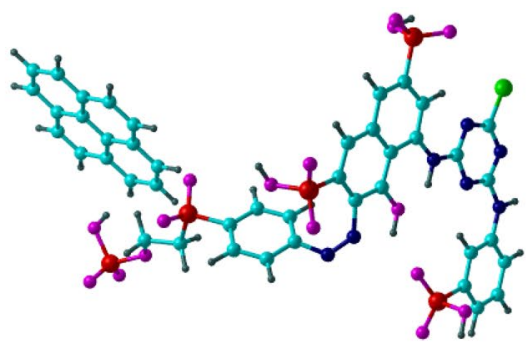

(b) Complex P2

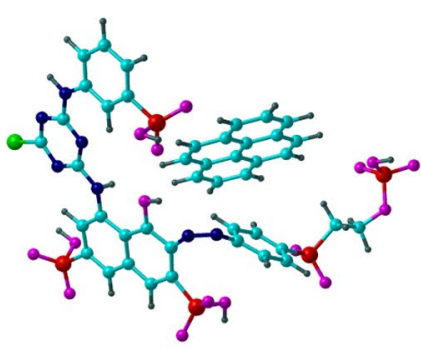

(e) Complex P5

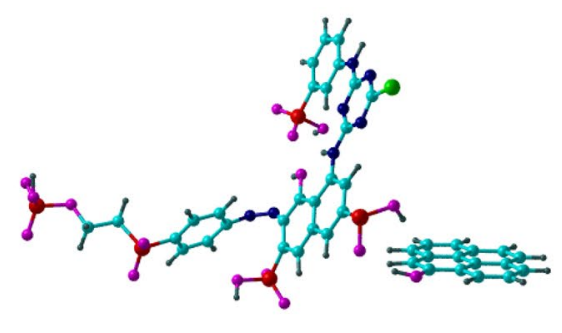

(c) Complex P3

Fig. 10 (a) Complex P1. (b) Complex P2. (c) Complex P3. (d) Complex P4. (e) Complex

Table 3 Binding energy using the B3LYP/6-31G(d) method

\begin{tabular}{llllll}
\hline & P1 & P2 & P3 & P4 & P5 \\
\hline Binding energy $(\mathrm{kJ} / \mathrm{mol})$ & 3.76 & 26.55 & 63.09 & -74.47 & 24.34 \\
\hline
\end{tabular}

5. Column adsorption process proved to be an efficient process which treated large amount of synthetic dyed wastewater using limited quantity of activated carbon from rice husk and successfully brought down all values of impurities to permissible limits.

6. Computations performed at the B3LYP/6-31G(d) method inferred that the complex $\mathrm{P} 3$ had the highest binding energy implying an endothermic chemisorption process.

7. For future applications, activated carbon from rice husk possesses good adsorptive characteristics and has good yield of $74.75 \%$. Therefore, large amount of activated carbon can be produced for treating wastewater which will eventually reduce environmental pollution and promotes sustainable development.

8. Finally, it can be concluded that the column adsorption process proved to be an effective and efficient process which treated large amount of synthetic dyed wastewater containing reactive red 195 dye up to $99.5 \%$ dye removal using a limited quantity of activated carbon from rice husk. In addition to this, from the results of the comparison between batch and column treat- ment, both process removed impurities from water, however, column adsorption successfully brought down all values of impurities to permissible limits set in the standard for industrial wastewater discharge in Mauritius.

Acknowledgements The authors acknowledge facilities at the University of Mauritius and the Extreme Science and Engineering Discovery Environment (XSEDE), which is supported by National Science Foundation grant number $\mathrm{OCl}-1053575$.

\section{Compliance with ethical standards}

Conflict of interest The authors declare that they have no conflict of interest.

\section{References}

1. Malik R, Ramteke D, Wate S (2007) Adsorption of malachite green on groundnut shell waste based powdered activated carbon. Waste Manag 27(9):1129

2. Zandipak R, Sobhanardakani S (2015) Synthesis of NiFe2O4 nanoparticles for removal of anionic dyes from aqueous solution. Desalin Water Treat 57(24):11348-11360

3. Ahiduzzaman M, Sadrul Islam AKM (2016) Preparation of porous bio-char and activated carbon from rice husk by leaching ash and chemical activation. Springerplus 5(1):1248

4. Bizuneh A (2012) Textile effluent treatment and decolorization techniques - a review. c 21(3):434 
5. Chincholi M, Sagwekar P, Nagaria C, Kulkarni SJ, Dhokpande SR (2014) Removal of dye by adsorption on various adsorbents: a review. Int J Sci Eng Technol 3(4):835

6. Admasu AD (2008) Adsorptive removal of reactive azo dyes using industrial residue. Master Thesis, School of Graduate Studies Addis Ababa University

7. Kumar SP, Ramalingam S, Ramasundaram VA, Selvaraj DK, Arukkani M, Subramanian S (2012) Adsorption of metal ions onto the chemically modified agricultural waste. CLEAN - Soil Air Water 40(2): 118

8. Tripathi N (2013) Cationic and anionic dye adsorption by agricultural solid wastes: a comprehensive review. J Appl Chem 5(3):91

9. Pereira L, Alves M (2012) Dyes-Environmental Impact and Remediation. In: Malik A, Grohmann E (eds) Environmental Protection Strategies for Sustainable Development. Strategies for Sustainability. Springer, Dordrecht

10. Salleh MAM, Mahmoud DK, Abdul Karim WAW, Idris A (2011) Cationic and anionic dye adsorption by agricultural solid wastes: a comprehensive review. Desalination 280(1-3):1-13

11. Wang Q, Chang X, Li D, Hu Z, Li R, He Q (2011) Adsorption of chromium(III), mercury(II) and lead(II) ions onto 4-aminoantipyrine immobilized bentonite. J Hazard Mater 186(2-3):1076

12. Parvathi $C$, Maruthvanan T, Sivamani S, Prakash C, Koushik CV (2010) Role of tapioca peel activated carbon (TPAC) in decolourisation of red brown C4R reactive dye. Indian J Sci Tech 3(3):290

13. Demirbas A (2009) Agricultural based activated carbons for the removal of dyes from aqueous solutions: a review. J Hazard Mater 167(1-3):1

14. Mishra I, Srivastav VC, Mall ID (2009). Competitive adsorption of cadmium(II) and nickel(II) metal ions from aqueous onto rice husk ash. Chem Eng Process 48(1):370

15. Babu BR, Parande AK, Raghu S, Kumar TP (2007) An overview of wastes produced during cotton textile processing and effluent treatment methods. J Cotton Sci 11:110

16. Ullhyan A (2014) Adsorption of reactive blue-4 dye from aqueous solution onto acid activated mustard stalk: equilibrium and kinetic studies. Glob J Biol Agric Health Sci 3(1):98

17. Akhtar $\mathrm{N}$ et al (2012) Application of chitosan padded rice and wheat husk for the removal of reactive dye from aqueous solution. Afr J Biotechnol 11(64):12756

18. Sahasrabudhe M, Pathade G (2012) Decolourization and degradation of C.I reactive red 195 by Georgenia sp. CC-NMPT-T3. Indian J Exp Biol 50(4):290

19. Dursun AY, Tepe $O$ (2011) Removal of chemazol reactive red 195 from aqueous solution by dehydrated beet pulp carbon. J Hazard Mater 194:303

20. Aksakal O, Ucun H (2010) Equilibrium, kinetic and thermodynamic studies of the biosorption of textile dye (Reactive Red 195) onto Pinus sylvestris L. J Hazard Mater 181(1-3):666

21. Worku A, Sahu O (2014) Removal of reactive dye from aqueous solution using physico-chemically treated rice husk. J Environ Treat Tech 2(3):77

22. Taha DN, Mohammed LA, Samaka IS (2012) Investigation on using rice-husk as low cost adsorbent for dye removal from industrial wastewater. In: The first scientific conference the collage of education for pure sciences, pp 139-153

23. Jeetah P, Golaup N, Buddynauth K (2015) Production of cardboard from waste rice husk. J Environ Chem Eng 3(1):52

24. Lacasse K, Baumann W (eds) (2004) Textile chemicals: environmental data and facts. Springer, Berlin Heidelberg

25. Saleh TA, S A, Gupta VK, Al-Saadi AA (2013) Adsorption of lead ions from aqueous solution using porous carbon derived from rubber tires: experimental and computational study. J Colloid Interface Sci 396:264

26. Frisch MJ, Trucks GW, Schlegel HB, Scuseria GE, Robb MA, Cheeseman JR, Scalmani G, Barone V, Mennucci B, Petersson GA,
Nakatsuji H, Caricato M, Li X, Hratchian HP, Izmaylov AF, Bloino J, Zheng G, Sonnenberg JL, Hada M, Ehara M, Toyota K, Fukuda R, Hasegawa J, Ishida M, Nakajima T, Honda Y, Kitao O, Nakai $\mathrm{H}$, Vreven T, Montgomery JA Jr, Peralta JE, Ogliaro F, Bearpark $M$, Heyd JJ, Brothers E, Kudin KN, Staroverov VN, Kobayashi R, Normand J, Raghavachari K, Rendell A, Burant JC, lyengar SS, Tomasi J, Cossi M, Rega N, Millam NJ, Klene M, Knox JE, Cross JB, Bakken V, Adamo C, Jaramillo J, Gomperts R, Stratmann RE, Yazyev O, Austin AJ, Cammi R, Pomelli C, Ochterski JW, Martin RL, Morokuma K, Zakrzewski VG, Voth GA, Salvador P, Dannenberg JJ, Dapprich S, Daniels AD, Farkas Ö, Foresman JB, Ortiz JV, Cioslowski J, Fox DJ (2010) Gaussian 09, Revision B.01. Gaussian Inc., Wallingford CT

27. Milfeld K, Guiang C, Pamidighantam S, Giuliani J (2005) Cluster computing through an application-oriented computational chemistry grid. In: Proceedings of the 2005 linux clusters: the HPC revolution

28. Dooley R, Milfeld K, Guiang C, Pamidighantam S, Allen G (2006) From proposal to production: lessons learned developing the computational chemistry grid cyberinfrastructure. J Grid Comput 4(2):195

29. Shen N, Fan Y, Pamidighantam S (2014) E-science infrastructures for molecular modeling and parametrization. J Comput Sci 5(4):576

30. Pamidighantam $S$, Nakandala $S$, Abeysinghe $E$, Wimalasena $C$, Rathnayakae S, Marru S, Pierce M (2016) Community science exemplars in SEAGrid science gateway: apache airavata based implementation of advanced infrastructure. Proc Comput Sci 80:1927

31. Kamchai N, Sarawut S, Samorn H (2010) Kinetics and equilibrium adsorption of basic green 4 dye on activated carbon derived from durian peel: effects of pyrolysis and post-treatment conditions. J Taiwan Inst Chem Eng 41(5):591

32. Ong $S$, Lee $W$, Keng $P$, Lee $S$, Hung $Y$, Ha $S$ (2010) Equilibrium studies and kinetics mechanism for the removal of basic and reactive dyes in both single and binary systems using EDTA modified rice husk. Int J Phys Sci 5(5):582

33. Sobhanardakani S, Zandipak R, Sahraei R (2013) Removal of Janus Green dye from aqueous solutions using oxidized multiwalled carbon nanotubes. Toxicol Environ Chem 95(6):909

34. Safa Y, Bhatti HN (2011) Kinetic and thermodynamic modelling for the removal of direct red-31 and direct orange-26 dyes from aqueous solutions by rice husk. Desalination 272(1-3):313

35. Beyene HA, Alemayehu AM (2013) Removal of Ni(II) from aqueous solution using leaf, bark and seed of moringa stenopetala adsorbents. Bull Chem Soc Ethiopia 27(1):35

36. Noor S, Rohasliney H (2012) Rice husk as biosorbent: a review. Health Environ J 3(1):89

37. Paul SA, Chavan SK (2013) Utilization of low cost rice husk for adsorption of sulphur dye: kinetics and isotherm study. Int J Res Chem Environ 3(1):219

38. Somasundaram S, Sekar K, Gupta VK, Ganesan S (2013) Synthesis and characterization of mesoporous activated carbon from rice husk for adsorption of glycine from alcohol-aqueous mixture. J Mol Liq 177:416

39. Sharma N, Tiwari DP, Singh SK (2012) Decolourisation of synthetic dyes by agricultural waste: a review. Int J Sci Eng Res 3(2):1

40. Patil C, Ratnamala GM, Channamallayya ST (2015) Adsorption studies for removal of acid yellow 17 using activated rice husk. Int Res J Eng Technol 2(5):769

41. Angin $D$ (2014) Utilization of activated carbon produced from fruit juice industry solid waste for the adsorption of yellow 18 from aqueous solutions. Bioresour Technol 168:259

42. Al-Husseiny HA (2014) Adsorption of methylene blue dye using low cost adsorbent of sawdust: batch and continues studies. $J$ Univ Babylon Eng Sci 22(2):296 
43. Halbus AF, Athab ZH, Hussein FH (2013) Adsorption of disperse blue dye on Iraqi date palm seeds activated carbon. Int J Chem Sci 11(3):1219

44. Sohn S, Kim D (2005) Modification of Langmuir isotherm in solution systems-definition and utilization of concentration dependent factor. Chemosphere 58(1):115

45. Mobasherpour I, Salahi E, Asjodi A (2014) Research on the batch and fixed-bed column performance of red mud adsorbents for lead removal. Can Chem Trans 2(1):83

46. Dixit A, Dixit S, Goswami CS (2014) Study of adsorption isotherms and thermodynamics for heavy metal removal from aqueous solutions using Canna indica biomass. Int J Sci Eng Res 5(2):876

47. Rahman MM, Hamidul Bari Q, Mohammad N, Ahsan A, Sobuz HR, Uddin MA (2013) Characterization of rice husk carbon produced through simple technology. Adv Mat Sci Appl 2(1):25

48. Igwe J, Abia A (2007) Adsorption isotherm studies of $\mathrm{Cd}(\mathrm{II}), \mathrm{Pb}$ (II) and $\mathrm{Zn}$ (II) ions bioremediation from aqueous solution using unmodified and EDTA-modified maize cob. Eclet Quím 32(1):33

49. Huang P, Berthelin J, Bollag JM, McGill WB (eds) (1995) Environmental impacts of soil component interactions: land quality, natural and anthropogenic organics, vol 1. CRC Press, Saskatoon

50. Ada K, Ergene A, Tan S, Yalcin E (2009) Adsorption of remazol brilliant blue R using $\mathrm{ZnO}$ fine powder: equilibrium, kinetic and thermodynamic modelling studies. J Hazard Mater 165(1-3):637

51. Hamdaoui $O$, Naffrechoux E (2007) Modeling of adsorption isotherms of phenol and chlorophenols onto granular activated carbon Part I. Two-parameter models and equations allowing determination of thermodynamic parameters. J Hazard Mater 147(1-2):381

52. Ho YS, Mckay G (1998) A comparison of chemisorption kinetic models applied to pollutant removal on various sorbents. Process Saf Environ Prot 76(4):332

53. Ghaedi M, Sadeghian B, Pebdani AA, Sahraei R, Daneshfar A, Duran C (2012) Kinetics, thermodynamics and equilibrium evaluation of direct yellow 12 removal by adsorption onto silver nanoparticles loaded activated carbon. Chem Eng J 187:133

54. Ho Y, McKay G (1999) Pseudo-second order model for sorption processes. Process Biochem 34(5):451

55. Tan IAW, Ahmad AL, Hameed BH (2008) Adsorption of basic dye using activated carbon prepared from oil palm shell: batch and fixed bed studies. Desalination 225(1-3):13

56. Hussain J, Hussain I, Arif M (2004) Characterization of textile wastewater. J Ind Pollut Control 20(1):137

57. Nollet $H$, Roels $M$, Lutgen $P$, Van der Meeren $P$, Verstraete $W$ (2003) Removal of PCBs from wastewater using fly ash. Chemosphere 53(6):655

58. Pathania D, Sharma S, Singh P (2017) Removal of methylene blue by adsorption onto activated carbon developed from Ficus carica bast. Arab J Chem 10:S1445

Publisher's Note Springer Nature remains neutral with regard to jurisdictional claims in published maps and institutional affiliations. 